\title{
SARS-CoV-2 seroprevalence in a high-altitude setting in Peru: Adult population-based cross-sectional study
}

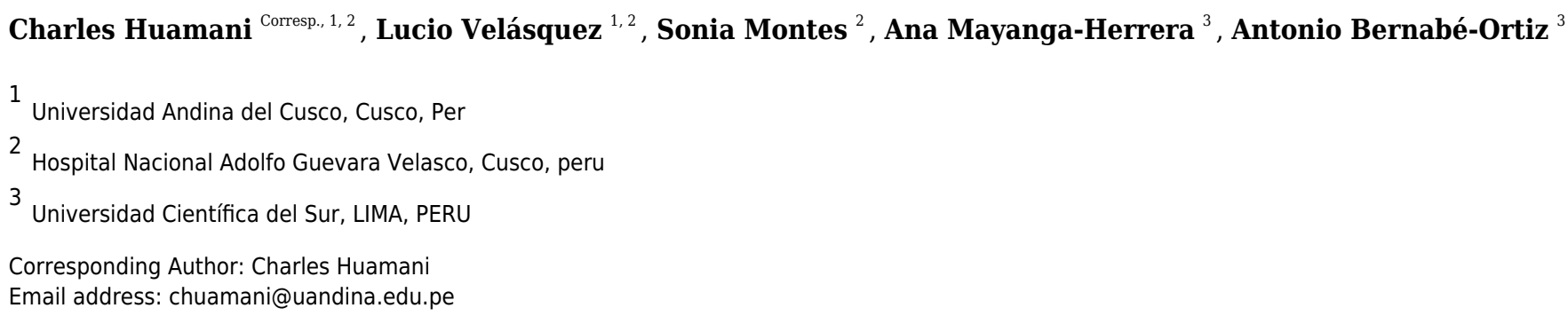

Background: There are several ecological studies, but few studies of the prevalence of SARS-COV-2 at high altitude. We aimed to estimate the population-based seroprevalence of SARS-COV-2 in three settings of Cusco at the end of the first wave among adults.

Methods: A population-based survey was conducted in September 2020, in three settings in the region of Cusco: (1) Cusco city at 3300 meters above the sea level (m.a.s.l.), (2) the periphery of Cusco (Santiago, San Jerónimo, San Sebastián, and Wanchaq) at 3300 m.a.s.l., and (3) Quillabamba city, located at 1050 m.a.s.I. People aged $\geq 18$ years within a family unit were included. The diagnosis of SARS-CoV-2 infection was based on identifying anti- SARS-CoV-2 total antibodies (IgM and IgG) in serum using the Elecsys Anti-SARS-

CoV-2 chemiluminescence test. Results: We enrolled 1924 participants from 712 families. Of the total, 637 participants were anti-SARS-CoV-2 seropositive. Seroprevalence was $38.8 \%$ (95\% Cl: $33.4 \%-44.9 \%)$ in Cusco city, 34.9\% (95\%Cl: $30.4 \%-40.1 \%$ ) in the periphery of Cusco, and $20.3 \%$ (95\%Cl: 16.2\%-25.6\%) in Quillabamba. In 141 families (19.8\%; $95 \% \mathrm{Cl}: 17.0 \%-22.8 \%$ ) the whole members were positive to the test. Living with more than three persons in the same house, a positive COVID-19 case at home, and a member who died in the last five months were factors associated with SARS-COV-2 seropositivity. Dysgeusia/dysosmia was the symptom most associated with seropositivity (aPR $=2.74$, 95\% Cl: 2.41-3.12); whereas always wearing a face shield ( $\mathrm{aPR}=0.73 ; 95 \% \mathrm{Cl}: 0.60-0.89$ ) or a facial mask ( $\mathrm{aPR}=0.76,95 \% \mathrm{Cl}: 0.63-0.92)$ reduced that probability. Conclusions: $\mathrm{A}$ great proportion of Cusco's city inhabitants presented anti-SARS-CoV-2 antibodies at the end of the first wave, with significant differences between settings. Wearing masks and face shields were associated with lower rate of seropositivity; however, efforts must be made to sustain them over time since there is still a high proportion of susceptible people. 


\section{SARS-CoV-2 seroprevalence in a high-altitude setting in Peru: Adult 2 population-based cross-sectional study}

3

4 Charles Huamaní1 ${ }^{1,2}$, MSc; Lucio Velásquez ${ }^{1,2}$, MPH; Sonia Montes ${ }^{2}$, MD; Ana Mayanga-

5 Herrera $^{3}, \mathrm{MSc}$; Antonio Bernabé-Ortiz ${ }^{3}, \mathrm{PhD}$

6

$7 \quad{ }^{1}$ Universidad Andina del Cusco, Cusco, Perú.

$8{ }^{2}$ Hospital Nacional Adolfo Guevara Velasco, EsSalud, Cusco, Perú.

$9{ }^{3}$ Universidad Científica del Sur, Lima, Perú.

10

11 Corresponding Author:

12 Charles Huamaní,

13 Email address: chuamani@uandina.edu.pe

14 Phone: +51992814710

15

16

\section{Abstract}

Background: There are several ecological studies, but few studies of the prevalence of SARS-COV-2 at high altitude. We aimed to estimate the population-based seroprevalence of SARS-COV-2 in three settings of Cusco at the end of the first wave among adults.

Methods: A population-based survey was conducted in September 2020, in three settings in the region of Cusco: (1) Cusco city at 3300 meters above the sea level (m.a.s.l.), (2) the periphery of Cusco (Santiago, San Jerónimo, San Sebastián, and Wanchaq) at 3300 m.a.s.1., and (3) Quillabamba city, located at 1050 m.a.s.l. People aged $\geq 18$ years within a family unit were included. The diagnosis of SARS-CoV-2 infection was based on identifying anti- SARS-CoV-2 total antibodies (IgM and IgG) in serum using the Elecsys Anti-SARS-CoV-2 chemiluminescence test.

Results: We enrolled 1924 participants from 712 families. Of the total, 637 participants were anti-SARSCoV-2 seropositive. Seroprevalence was 38.8\% (95\%CI: 33.4\%-44.9\%) in Cusco city, 34.9\% (95\%CI: $30.4 \%-40.1 \%$ ) in the periphery of Cusco, and 20.3\% (95\%CI: 16.2\%-25.6\%) in Quillabamba. In 141 families $(19.8 \%$; $95 \% \mathrm{CI}: 17.0 \%-22.8 \%)$ the whole members were positive to the test. Living with more than three persons in the same house, a positive COVID-19 case at home, and a member who died in the last five months were factors associated with SARS-COV-2 seropositivity. Dysgeusia/dysosmia was the 
32 symptom most associated with seropositivity ( $\mathrm{aPR}=2.74,95 \% \mathrm{CI}$ : 2.41-3.12); whereas always wearing a

33 face shield $(\mathrm{aPR}=0.73$; 95\% CI: 0.60-0.89) or a facial mask $(\mathrm{aPR}=0.76,95 \% \mathrm{CI}: 0.63-0.92)$ reduced that 34 probability.

35 Conclusions: A great proportion of Cusco's city inhabitants presented anti-SARS-CoV-2 antibodies at the

\section{Introduction}

Worldwide, the Coronavirus Disease 19 (COVID-19) pandemic, caused by SARS-CoV-2 virus, has been evaluated in real-time through the official notifications of the affected countries (World Health Organization 2020b), which usually come from passive surveillance systems. However, a great proportion of individuals infected by SARS-CoV-2 virus remains undetected, especially in resource-constrained settings, as they usually are asymptomatic (Gandhi et al. 2020), and there is a lack of appropriate access to diagnosis in the health care system, generating a gap in the information for appropriate decisions (Byambasuren et al. 2020; Eckerle \& Meyer 2020). To deal with these issues, multiple population-based surveys have been conducted around the world (Franceschi et al. 2020; Lai et al. 2020; Rostami et al. 2020), with divergent results as countries are in different epidemiological scenarios, i.e., beginning or end of the first pandemic wave, urban/rural areas, national/regional representation, or different diagnostic test used (molecular, antibody, or antigen detection tests). Even so, reported prevalence has usually been lower than $20 \%$ after the end of the first wave (Rostami et al. 2020).

Few studies have been published in low- and middle-income countries, including Latin American countries (Lai et al. 2020; Rostami et al. 2020), where because different social determinants (e.g. poverty levels, inequities, overcrowding, and a weak health system), a higher anti-SARS-CoV-2 antibodies prevalence could be expected (Burki 2020; Pablos-Méndez et al. 2020). Moreover, many of the studies in high-altitude cities (i.e., those located over 2500 meters above the sea level [m.a.s.1.]) (Arias-Reyes et al. 2020; CanoPérez et al. 2020; Segovia-Juarez et al. 2020; Thomson et al. 2021; Woolcott \& Bergman 2020) are ecological in nature. Ecological studies include only registered cases; thus, the percentage of underreporting is high due to asymptomatic forms, diagnostic deficiencies, limitations to access health services, among others. These limitations are not present in studies like ours, as they are based on probabilistic samples and not only in the presence of symptoms. Also, many ecological studies have suggested that the impact of the COVID-19 pandemic would be low because unclear environmental determinants such as atmospheric 
64 pressure or radiation (Segovia-Juarez et al. 2020; Thomson et al. 2021). However, the pandemic progression

65 is more linked to social interaction and adopted preventive measures (Huamaní et al. 2020).

66 By September 2020, Peru had registered more than 900 thousand confirmed cases and more than 32

67 thousand deaths attributed to the pandemic (Ministerio de Salud 2021). For that reason, Peru has been on

68 the top of number deaths by COVID-19 per for millions of people in South America (World Health

69 Organization 2020b). The Peruvian government response to the pandemic was prompt, including

70 mandatory social distancing measures, mandatory use of masks, and re-focusing most health system

71 resources to address the pandemic. Peru is a very heterogeneous country with a variable geography, thus,

72 although the first case of SARS-COV-2 was detected in March 2020, some high-altitude cities like Cusco

73 experienced the first wave between July and September (Dirección Regional de Salud de Cusco 2020). At

74 the end of this period, we conducted a population-based seroprevalence of anti-SARS-CoV-2 antibodies

75 in different areas of Cusco, and evaluated some determinants associated with the spread of the SARS-

76 CoV-2 seropositivity.

77

\section{Materials \& Methods}

\section{Study design}

80 A population-based cross-sectional study was conducted between September 12 and 27, 2020 in the region 81 of Cusco, Peru.

82

\section{Study locations}

84 The region of Cusco comprises thirteen provinces, each having a different number of cities (Figure 1).

85 Cities offering variability of scenarios were chosen due to their proportion of urban/rural areas, altitude, 86 and population. Three different study settings were selected as follows:

87 - Cusco city, Province of Cusco, with a high demographic density (approximately 1000 inhabitants $/ \mathrm{km}^{2}$ ), 88 population (125,000 inhabitants), and located at 3330 m.a.s.l. Based on the information available about the 89 behavior of the COVID-19 pandemic in the region (Dirección Regional de Salud de Cusco 2020), it would 90 represent the worst transmission scenario.

91 - Periphery of Cusco, Province of Cusco, including different cities around the Cusco city (Santiago, San 92 Sebastián, San Jerónimo, and Wanchaq), where approximately 320,000 inhabitants in total live 93 (approximately 1100 inhabitants $/ \mathrm{km}^{2}$ ). Although these cities are at the same altitude as Cusco city, they are 94 located on the historic center's periphery.

95 - Quillabamba City, Province of La Convención, located at the lowest altitude in the department of Cusco 96 (1050 m.a.s.1.) with an approximate population of 30,000 inhabitants, and geographically distant 97 (approximately 6 hours by road, not accessible by any other way), with a low population density $(<10$ 
98

99

100

101

\section{Participants and sampling}

103

104

105

106

107

108

109

110

111

112

113

114

115

116

117

118

119

120

121

122

123

124

125

126

127

128

129

130

131

\section{Procedures}

inhabitants $/ \mathrm{km}^{2}$ ). This city is part of the Peruvian jungle and, as a result, the climate and geography are different from that of Cusco city. Despite of that, during the first wave, La Convencion was the second Province of Cusco with the most reported cases (Dirección Regional de Salud de Cusco 2020).

People aged $\geq 18$ years old, who voluntarily agreed to participate in the study, signed their informed consent, accepted the telephone and serological follow-up, usual resident of the study area ( $\geq 6$ months), and with the ability to understand the procedures were included. We did not exclude people with acute symptoms or who had already given positive results to previous tests.

A two-stage probability sampling approach was carried out: by clusters of groups of blocks and by households. Maps by each of the cities were used as sampling frame. The primary sampling unit was defined as the cluster comprised by a block or group of blocks with approximately 40 households. In the Cusco city, 98 clusters were created, whereas these numbers were 495 and 74 for the periphery of Cusco and Quillabamba, respectively. Of them, 10, 16 and 8 clusters were randomly chosen in each of the settings, respectively. Within each cluster, households were selected randomly. In each selected household, all the members who met the eligibility criteria were included until the intended sample size was achieved.

The sample size calculation was based on an expected population prevalence of at least $5 \%$, precision of $2.5 \%$, a confidence level of $95 \%$, and a design effect of 2 . Based on these estimates, the required sample size in a conservative setting was 1752 participants for the three settings. With this sample size, we had a power over $80 \%$ to detect a difference in the prevalence of SARS-CoV-2 seropositivity of at least $5 \%$ (e.g., $5 \%$ vs. $10 \%$ ) between the groups of interest (study setting and gender). Therefore, at least 1800 participants had to be enrolled for the three settings, considering losses to follow-up, and split into 600 participants for Cusco city, 800 for the periphery of Cusco, and 400 for Quillabamba.

The collection of information and biological samples was carried out during three weekends in September $2020(12,13,19,20,26$ and 27) taking advantage of the period of lockdown in the region. Data and sample collection were prioritized during Sundays to guarantee the presence of the largest number of family members. The field staff visited each household to contact potential participants, assess eligibility, invite them to participate in the study, apply the informed consent, questionnaires, and finally, take blood samples. The questionnaire evaluated sociodemographic characteristics (age, gender, etc.), comorbidities (self-report of hypertension, diabetes, asthma, cancer, renal or cardiac disease), weight and height (self-reported and with that, the BMI was calculated), obesity (BMI $>=30$ ), number of people living together, past case at home of a patient with COVID-19, a family member who died in the last five months, among others. We 
132 included questions about symptoms developed in the last three months, self-report of any previous SARS-

133 COV-2 diagnostic test (rapid or molecular test) performed in the last three months (tests are periodically

134 done in some populations as part of the government indications. Thus, with this question we tried to know

135 if the test of the survey was the first of the participant), and protective behaviors used or applied during

136 quarantine (when leaving home, you have always used... a mask, alcohol for hand disinfection, gloves,

137 etc.), including those mandatories for use by the government, but not regulated or sanctioned, such as the 138 use of masks.

139 Once the questionnaire was completed, a blood sample of $3.5 \mathrm{~mL}$ of whole blood was taken in serum 140 separating tubes. Each tube was coded and stored for transportation. The samples were stored between 2 to $1418^{\circ} \mathrm{C}$ for up to 5 days, according to the World Health Organization guidelines (World Health Organization 142 2020a).

143 Chemiluminescence tests were used for serological detection of antibodies against SARS-CoV-2 Elecsys 144 from the ROCHE laboratory. This test is based on a sandwich-type immunoassay, where the recombinant 145 protein $\mathrm{N}$ of SARS-CoV-2 is the target detected by possible antibodies present in the serum sample 146 (ROCHE S.A.C 2020). The test detects total antibodies simultaneously, without differentiating between 147 IgM or IgG. This test has a specificity of $99.5 \%$, and whether the test is performed after 14 days of having 148 a positive result by PCR, the sensitivity may reach up to 99.8\% (Muench et al. 2020). In an evaluation 149 carried out at the Instituto Nacional de Salud (NHI) of Peru, it was confirmed that the sensitivity was 96.7\% 150 and the specificity was $98.6 \%$ (Instituto Nacional de Salud-Peru).

151

\section{Statistical analysis}

153 For data analysis, STATA 16 for Windows (StataCorp, College Station, TX, US) was utilized. The 154 description of the study population was carried out according to the characteristics of interest. The 155 prevalence of serum antibodies against SARS-CoV-2 virus (percentage of people seropositive to SARS156 CoV-2) was estimated, taking into account the sampling techniques used. Prevalence estimates and 157 regression analysis were calculated using Poisson distribution models adjusting for clusters at household 158 level and with robust variance. Regression models were used to identify the factors associated with 159 positivity for SARS-COV-2, obtaining adjusted prevalence ratios (aPR) for study settings, gender, and age 160 group ( $<40,40-59$, and $60+$ years of age), considering clusters at the household level. No other variables 161 were included in the adjusted model because they did not show changes in the results and an attempt was 162 made to preserve the parsimony of the model. All estimates are presented with $95 \%$ confidence intervals $163(95 \% \mathrm{CI})$.

164

\section{Ethics}


166 The study was approved by the Ethics Committee of the Universidad Científica del Sur (code 051-2020-

167

168

169

170

171

172

173

174

175

176

177

178

179

180

181

182

183

184

185

186

187

188

189

190

191

192

193

194

195

196

197

198

PRO99). Written informed consent was used, and although personal identifiers were collected, this was done to guarantee appropriate delivery of test results. All the results were delivered directly to study participants. To reduce the risks of contagion by SARS-CoV-2 virus during the execution of the research project, all the interviewers followed the protocols for handling COVID-19 patients and providing masks to study participants. The participants had access to help lines, where trained physicians answered their questions and provided guidance concerning COVID-19.

\section{Results}

\section{Characteristics of the study population}

A total of 712 families (range: 1 to 11 members included) were enrolled in the present study, with a total of 1924 participants being evaluated. Of them, 408 (21.2\%) were from Quillabamba, 640 (33.3\%) were from Cusco city, and 876 (45.5\%) were from the periphery of Cusco. The average age was 42.5 (SD: 16.5), and 1096 (57.1\%) were women; these characteristics were not different between the different study settings. However, self-reported obesity was more frequent (26.5\%) in Quillabamba compared to Cusco city (13.2\%) or the periphery of Cusco $(18.3 \%$, p-value $<0.001)$. The characteristics of the study population, according to the study settings, are shown in Table 1.

Overall, 39.7\% (95\%CI: $36.8 \%-42.9 \%$ ) of participants indicated at least one previous test to detect SARSCOV-2. Being asymptomatic $(\mathrm{aPR}=0.79,95 \% \mathrm{CI}$ : 0.69-0. 91$)$ or being a woman $(\mathrm{aPR}=0.82,95 \% \mathrm{CI}$ : 0.74-0.91) reducing the probability of having a previous test; whereas higher education ( $>12$ years) increased such probability ( $\mathrm{aPR}=1.32,95 \% \mathrm{CI}: 1.23-2.13)$.

From 606 families that reported information, 46 (7.6\%) stated that at least one member died in the 5 months previous to the survey, and from these, $60.5 \%$ attributed the cause of death to COVID- 19.

\section{Prevalence of anti-SARS-CoV-2 antibodies}

A total of 637 participants were reactive to the screening test, which defines an adjusted prevalence of $33.1 \%$ (95\%CI: $30.1 \%-36.4 \%$ ). This prevalence varied according to the study settings: $20.3 \%$ (95\%CI: 16.2\%-25.6\%) in Quillabamba, 38.8\% (95\% CI: 33.4\%-44.9\%) in Cusco city, and 34.9\% (95\%CI: 30.4\%$40.1 \%$ ) in the periphery of Cusco (Table 2, extended analysis on supplementary table).

Of the 712 families evaluated, 318 (44.6\%; 95\% CI: 41.0\%-48.3\%) had at least one infected member, and 141 (19.8\%; 95\% CI: $17.0 \%-22.8 \%$ ) families had the whole members positive to the test.

\section{Factors associated with SARS-CoV-2 seropositivity}

Peer] reviewing PDF | (2021:03:58709:2:0:NEW 9 Aug 2021) 
199 Characteristics such as gender, education level, BMI category, or personal history of diseases were not 200 associated with changes in the probability of being positive for anti-SARS-CoV-2 antibodies ( $p>0.05)$. The 201 prevalence of anti-SARS-CoV-2 antibodies was lower in those aged $\geq 60$ years (26.2\%; 95\%CI: 20.7\%$20233.1 \%$ ). Other factors associated with seropositivity were living with 3 or more people, a family member 203 with previous SARS-CoV-2 infection and have a deceased member in the household in the last five months 204 (Table 3).

205 Overall, 40.2\% (95\% CI: 37.3\%-43.4\%) of participants had no symptoms in the three months prior to the 206 interview; however, 24.4\% (95\% CI 20.7\%-28.6\%) of them were positive for anti-SARS-CoV-2 antibodies. 207 Among those who developed any symptoms, 39.0\% (95\% CI: 35.2\%-43.2\%) were positive for anti-SARS208 CoV-2 antibodies. Having no symptoms was associated with a 43\% reduction in the probability of having 209 anti-SARS-CoV-2 antibodies (aPR $=0.68,95 \%$ CI: 0.58-0.81); however, some symptoms increased the 210 probability of having anti-SARS-CoV-2 antibodies, such as dysgeusia/dysosmia (aPR $=2.74,95 \mathrm{CI} \% 2.41$ $2113.12)$ and respiratory distress ( $\mathrm{aPR}=2.18,95 \% \mathrm{CI}: 1.84-2.62)$.

212 Finally, 1473 (92.2\%) reported accomplishing with some protective behaviors; using at least one of them 213 decreased the probability of having anti-SARS-CoV-2 antibodies by $32 \%$ (aPR=0.68, 95\% CI: 0.55-0.87).

214 Specifically, always wearing a face shield decreased by $27 \%(\mathrm{aPR}=0.73,95 \% \mathrm{CI}: 0.6-0.89)$ the probability 215 of being positive for anti-SARS-CoV-2 antibodies, whereas the use of face masks decreased it by $24 \%$ $216(\mathrm{aPR}=0.76,95 \% \mathrm{CI}: 0.63-0.92)$, and the use of alcohol to hand disinfection by $33 \%(\mathrm{aPR}=0.78,95 \% \mathrm{CI}$ $2170.65-0.92)$.

218

\section{Discussion}

\section{Principal findings}

221 Our results indicate that, on average, a third of the population of Cusco had antibodies against SARS-CoV-2 222 virus, expanding our knowledge about the epidemiology of COVID-19 pandemic in high-altitude settings, 223 which is a very high result compared to other seroprevalence studies in different settings and countries. 224 These results may be appropriately contextualized to understand the varying spread and transmission of the 225 epidemic (Eckerle \& Meyer 2020; Kucharski et al. 2020). In Peru, a mandatory social lockdown, suspension 226 of tourism, and internal migration were quickly adopted after the detection of the first COVID-19 case 227 (Presidencia del Consejo de Ministros 2020); therefore, the first wave was presented relatively late 228 compared to other countries in the region. Cusco reported the first positive case in March 2020; but it was 229 not until June that a sustained increase in cases was identified, reaching the peak in August, and a decreased 230 occurred since September (Dirección Regional de Salud de Cusco 2020). Thus, our results were collected 231 immediately after the end of the first wave in Cusco, and results should be compared with studies in a 232 similar epidemiological situation. 
233 Prevalence of anti-SARS-CoV-2 antibodies may differ depending upon the pandemic stage. A nationwide 234 study in Spain reported a prevalence of 5\% (Pollán et al. 2020) with markedly geographical variation (up 235 to $10 \%$ in Madrid); however, a study in a region of Brazil, reported a population-based prevalence of $40 \%$ 236 (Silva et al. 2020). Another study reported 16\% in Chile, but was $24.5 \%$ in the Metropolitan region (Brault 237 2021). Studies in other countries have not yet been officially published.

238 In Peru, some seroprevalence studies have already been reported; for example, during June-July 2020, the 239 prevalence in Lima was estimated in 25.2\% (Reyes-Vega et al., 2021), while in Cusco was 2.6\% (Dirección 240 Regional de Salud de Cusco \& Gobierno Regional Cusco 2020). However, Lima had the peak of infections 241 in June 2020 compared to August in Cusco. Other Peruvian cities have also reported high prevalence at the 242 end of their first wave, such as Lambayeque (located on the northern coast of Peru and strongly affected) 243 where the prevalence was $29.5 \%$ by June-July (Díaz-Vélez et al. 2021), and it was $71 \%$ in Iquitos (located 244 in the Peruvian jungle), the highest reported in the country (Ministerio de salud 2020). These studies used 245 lateral immunochromatography tests (rapid tests) as a diagnostic method, which have obtained a diagnostic 246 yield of less than 50\% sensitivity in a field validation in Peru (Vidal-Anzardo et al. 2020). In the world, the 247 tests used in prevalence studies are ELISA, chemiluminescence (CLIA), lateral flow chromatography 248 (LFIA), or fluorescence immunoassays (FIA). In a systematic review of the validity of these tests, it 249 indicates that the CLIA and ELISA tests for SARS-COV-2 have levels of sensitivity greater than 90\%, 250 while those of LFIA are in the range of 80 to $89 \%$ (Kontou et al. 2020). Although LFIA tests are more 251 attractive for seroprevalence studies, prevalence adjustments must be made due to their low sensitivity. We 252 used, however, CLIA tests, which in a validation against PCR-positive Peruvian samples for SARS-COV2532 and negative samples, stored since before the pandemic, showed a diagnostic yield greater than 95\%; as 254 a result, we consider that our estimates do not require other adjustments (Instituto Nacional de Salud of 255 Peru Lima, 2020).

256 In addition, our results show a marked difference in seroprevalence rates between cities in the same region. 257 While, on average, we have a prevalence of 33\%, this estimate in Cusco city almost doubled that of 258 Quillabamba (38\% vs. 20\%). The national seroprevalence study, carried out in April 2020, in Spain (Pollán 259 et al. 2020), has already shown that cities with $>100,000$ inhabitants have higher prevalence, probably due 260 to more significant social interaction, as could happen in our study, where the Cusco city, with high 261 demographic density, and the periphery of that city, were markedly affected. This has also been seen in 262 other studies, where urban cities have a higher prevalence than those in rural locations, as in our study 263 (Brault 2021).

264 Some ecological studies evaluating contagion at high-altitudes cities reported that at higher altitudes were 265 associated with lower frequency of the disease (Arias-Reyes et al. 2020; Cano-Pérez et al. 2020; Segovia266 Juarez et al. 2020; Thomson et al. 2021; Woolcott \& Bergman 2020), Contrary to these, the prevalence in 
267 our study was inverse to the altitude of the city, but potentially correlated with population density. 268 Ecological design studies are important to propose hypotheses, but these have important biases (Aggarwal 269 \& Ranganathan 2019; Gnaldi et al. 2018; Gordis 2009; Lancaster et al. 2006; Rousson et al. 2017). In the 270 case of the COVID-19 pandemic, ecological studies are based on data from registration by surveillance 271 systems that have great limitations (unidentified asymptomatic, different diagnostic criteria, passive 272 registration, etc.), especially in cities located at high altitudes, which have less access to health services and 273 a higher rate of poverty, so it is necessary to be very cautious when considering them. In our study, altitude 274 does not appear to be a unique associated factor, though it will not be easily determined. Our study shows 275 that in an urbanized city with a high population density, the prevalence is high regardless of the altitude at 276 which they are located (Table 4). These factors would condition the prevalence of a disease (Huamaní et 277 al. 2020); ecological studies do not usually include analyses of these confounding variables. Furthermore, 278 ecological studies can hardly measure prevalence, especially when the disease has a high percentage of 279 unidentified cases.

\section{Factors associated with the seropositivity of SARS-CoV-2}

281 Our results are consistent regarding some factors associated with a greater probability of positivity to anti282 SARS-CoV-2 antibodies, for example, the symptoms described such as anosmia or respiratory distress, in 283 the context of the pandemic, have a strong disease predictive association (Martin-Sanz et al. 2020). In recent 284 systematic reviews and meta-analyses, anosmia has been similarly associated with anti-SARS-CoV-2 285 antibodies with an OR between 11 and 14 (Aziz et al. ; Pang et al. 2020). In our study, we used the 286 prevalence ratio (PR) as an indicator because the prevalence of the disease was high $(>20 \%)$ and the OR could overestimate the strength of the association. But when logistic regression analysis was conducted, the OR for dysgeusia/dysosmia, the OR was 14.27 (8.24-24.7), similar to that found in systematic reviews. At the beginning of the pandemic, the first publications focused on contagion processes between contiguous people, such as clusters of families (Chan et al. 2020; Qian et al. 2020). These reports indicated that transmission between members of a family was not total, despite the existence of contact between the family members. The secondary attack rate among members of a family was around 36\% (Grijalva et al. 2020), however, in population seroprevalence studies, intra-domiciliary transmission has not been studied. In our study, if one family member was positive, in $44 \%$ of the cases all family members were positive. This result 296 may be more relevant for the purposes of adjusting the mathematical models of intra-household transmission.

298 Chronic diseases, such as hypertension, diabetes or obesity have already been described as predictors of poor prognosis of COVID-19 (Xu et al. 2020); therefore in Peru, the isolation of people with these diseases was recommended. Our study did not evidence that people with these antecedents had a different probability of contagion. In contrast, the older age groups ( $>60$ years) do present a lower risk, perhaps due to the lower 
301 exposure as they do not have the same needs to leave home or because the other members of their family 302 protected them. In Peru, only $12 \%$ of the population is older than 60 years old (in our study, it represents $30325 \%$ ), so the social behavior directed towards this vulnerable population may be protective and would 304 explain the low prevalence in this group of age (Instituto Nacional de Estadistica e Informática - Peru 2020), 305 and as they are a population with low prevalence and high susceptibility, vaccination could show greater 306 effectiveness than in the young population.

307 The actions of social distancing, wearing masks, and protection, in general, are included in several 308 recommendations to reduce the spread of the infection, although there were discrepancies in their use (limit 309 it only to symptomatic people, people at risk, among others) (Feng et al. 2020). The quantitative reduction 310 value in contagion possibilities was evaluated in multiple studies, which resulted in a meta-analysis with 311 positive results in favor of these measures (Chu et al. 2020). We identified a protective factor between 30\% 312 and $35 \%$ in practicing these measures, which leads us to continue recommending them. Although there is 313 a decrease in risk, we could not identify some protective factors such as social distancing or hand washing, 314 due to insufficient statistical power.

315 Since these measures are effective, inexpensive and easy to implement, it would be expected to be of general 316 use. A study carried out in China during the pandemic early phase found that at least $84 \%$ of the population 317 complied with some protection measure (Niu et al. 2020), in our study at the end of the first wave, it was 318 observed that $92 \%$ of participants reported always followed some of the measures evaluated. Although the 319 use was better accepted at the beginning of the pandemic, after the first wave, a decrease in use was 320 expected, especially since Peru does not have a tradition in the widespread and constant use of masks or 321 other protective measures.

\section{Limitations}

323 Our study is not representative for the whole Cusco region because of access to cities and distance among 324 them was not easy in lockdown times. However, the representativeness of the cities with the largest 325 population size and most affected was prioritized to facilitate decision-making in public health in the region, 326 knowing that the prevalence is also lower in the cities with smaller population size.

327 Additionally, despite the indication of lockdown at the beginning of our study, the population had to work 328 outside their homes; for this reason, the sample collection was mainly on Sundays to guarantee 329 representativeness of the population.

330 In our study we used tests that detected total antibodies, and our results might not be easily compared with 331 other studies that used tests that differences between $\operatorname{IgM}$ and IgG. However, the calculation of the 332 prevalence of a disease is based on the identification of new and old cases, therefore, the development of 333 one or another antibody allows them to be classified as "case". Therefore, for the objectives of our study, 334 there were no implications in the discrimination of $\operatorname{IgM}$ and $\operatorname{IgG}$ antibodies. 
335

336

337

338

339

340

341

342

343

344

345

346

347

348

349

\section{0}

351

352

353

354

355

356

357

358

359

360

361

362

363

364

365

366

367

368

369

370

371

372

373

A high rejection rate may influence the characteristics of the data. Whereas rejection rate was not collected, it was not frequently reported by the supervisory team. Even so, individuals from Quillabamba rejected participation more than subjects from other settings.

Also, in Cusco there is little availability of confirmatory tests such as molecular tests, so we cannot confirm the diagnoses. However, the evaluation carried out at the National Institute of Health of Peru demonstrated a high reliability of the test of the test used in our study. Finally, lack of power can be an issue as some associations were not significant, although these showed a suggestive trend.

\section{Conclusions}

In conclusion, at the end of the first wave, the seroprevalence found in Cusco city, a high-altitude setting, was high, with significant differences between areas. The factors associated with a lower probability of having anti-SARS-CoV-2 antibodies have been widely recommended (wearing a mask, use of alcohol and hand washing), but efforts must be made to sustain them over time since there is still a high proportion of susceptible people.

\section{Acknowledgements}

We would like to thank to the more than 40 professionals and medical students who participated in the execution of the study.

\section{References}

Aggarwal R, and Ranganathan P. 2019. Study designs: Part 2 - Descriptive studies. Perspect Clin Res 10:34-36. 10.4103/picr.PICR_154_18

Arias-Reyes C, Zubieta-DeUrioste N, Poma-Machicao L, Aliaga-Raduan F, Carvajal-Rodriguez F, Dutschmann M, Schneider-Gasser EM, Zubieta-Calleja G, and Soliz J. 2020. Does the pathogenesis of SARS-CoV-2 virus decrease at high-altitude? Respiratory physiology \& neurobiology 277:103443. https://doi.org/10.1016/j.resp.2020.103443

Aziz M, Goyal H, Haghbin H, Lee-Smith WM, Gajendran M, and Perisetti A. The Association of Loss of Smell to COVID-19: A Systematic Review and Meta-Analysis. The American Journal of the Medical Sciences. 10.1016/j.amjms.2020.09.017

Brault A. 2021. Seroprevalence of SARS-CoV-2 in Chile. Center for Mathematical Modeling, Universidad de Chile.

Burki T. 2020. COVID-19 in Latin America. The Lancet Infectious Diseases 20:547-548. 10.1016/S1473-3099(20)30303-0

Byambasuren O, Dobler CC, Bell K, Rojas DP, Clark J, McLaws M-L, and Glasziou P. 2020. Estimating the seroprevalence of SARS-CoV-2 infections: systematic review. medRxiv.

Cano-Pérez E, Torres-Pacheco J, Fragozo-Ramos MC, García-Díaz G, Montalvo-Varela E, and Pozo-Palacios JC. 2020. Negative Correlation between Altitude and COVID-19 Pandemic in Colombia: A Preliminary Report. Am J Trop Med Hyg 103:2347-2349. 10.4269/ajtmh.20-1027 
374

375

376

377

378

379

380

381

382

383

384

385

386

387

388

389

390

391

392

393

394

395

396

397

398

399

400

401

402

403

404

405

406

407

408

409

410

411

412

413

414

415

416

417

418

419

420

421

422

423

424

Chan JF-W, Yuan S, Kok K-H, To KK-W, Chu H, Yang J, Xing F, Liu J, Yip CC-Y, Poon RW-S, Tsoi H-W, Lo SK-F, Chan K-H, Poon VK-M, Chan W-M, Ip JD, Cai J-P, Cheng VC-C, Chen H, Hui CK-M, and Yuen K-Y. 2020. A familial cluster of pneumonia associated with the 2019 novel coronavirus indicating person-to-person transmission: a study of a family cluster. The Lancet 395:514-523. https://doi.org/10.1016/S0140-6736(20)30154-9

Chu DK, Akl EA, Duda S, Solo K, Yaacoub S, Schünemann HJ, Chu DK, AkI EA, El-harakeh A, Bognanni A, Lotfi T, Loeb M, Hajizadeh A, Bak A, Izcovich A, Cuello-Garcia CA, Chen C, Harris DJ, Borowiack E, Chamseddine F, Schünemann F, Morgano GP, Muti

Schünemann GEU, Chen G, Zhao H, Neumann I, Chan J, Khabsa J, Hneiny L, Harrison L, Smith M, Rizk N, Giorgi Rossi P, AbiHanna P, El-khoury R, Stalteri R, Baldeh T, Piggott T, Zhang Y, Saad Z, Khamis A, Reinap M, Duda S, Solo K, Yaacoub S, and Schünemann HJ. 2020. Physical distancing, face masks, and eye protection to prevent person-to-person transmission of SARS-CoV-2 and COVID-19: a systematic review and meta-analysis. The Lancet 395:1973-1987. https://doi.org/10.1016/S0140$6736(20) 31142-9$

Díaz-Vélez C, Failoc-Rojas VE, Valladares-Garrido MJ, Colchado J, Carrera-Acosta L, Becerra M, Moreno Paico D, and Ocampo-Salazar ET. 2021. SARS-CoV-2 seroprevalence study in Lambayeque, Peru. June-July 2020. PeerJ 9:e11210-e11210. 10.7717/peerj.11210

Dirección Regional de Salud de Cusco. 2020. Sala Situacional de COVID-19 Regional CUSCO. Available at http://www.diresacusco.gob.pe/new/salacovid19 (accessed 04/08/20.

Dirección Regional de Salud de Cusco, and Gobierno Regional Cusco. 2020. Prevalencia COVID-19 Provincia de Cusco. Reporte Epidemiológico COVID-19 Nº 006/DIRESA Cusco. Available at http://www. diresacusco.gob.pe/new/archivos/4335 (accessed 25/06/2020.

Eckerle I, and Meyer B. 2020. SARS-CoV-2 seroprevalence in COVID-19 hotspots. The Lancet 396:514-515. 10.1016/S0140-6736(20)31482-3

Feng S, Shen C, Xia N, Song W, Fan M, and Cowling BJ. 2020. Rational use of face masks in the COVID-19 pandemic. The Lancet Respiratory Medicine 8:434-436. 10.1016/S22132600(20)30134-X

Franceschi VB, Santos AS, Glaeser AB, Paiz JC, Caldana GD, Machado Lessa CL, de Menezes Mayer A, Küchle JG, Gazzola Zen PR, and Vigo A. 2020. Population-based prevalence surveys during the Covid-19 pandemic: A systematic review. Reviews in Medical Virology.

Gandhi M, Yokoe DS, and Havlir DV. 2020. Asymptomatic Transmission, the Achilles' Heel of Current Strategies to Control Covid-19. New England Journal of Medicine 382:21582160. 10.1056/NEJMe2009758

Gnaldi M, Tomaselli V, and Forcina A. 2018. Ecological Fallacy and Covariates: New Insights based on Multilevel Modelling of Individual Data. International Statistical Review 86:119135. https://doi.org/10.1111/insr.12244

Gordis L. 2009. Epidemiology. Forth edition: United States of America: Elsevier.

Grijalva CG, Rolfes MA, Zhu Y, McLean HQ, Hanson KE, Belongia EA, Halasa NB, Kim A, Reed C, Fry AM, and Talbot HK. 2020. Transmission of SARS-COV-2 Infections in Households - Tennessee and Wisconsin, April-September 2020. MMWR Morbidity and mortality weekly report 69:1631-1634. 10.15585/mmwr.mm6944e1

Huamaní C, Velásquez L, Montes S, and Miranda-Solis F. 2020. Propagation by COVID-19 at high altitude: Cusco case. Respiratory physiology \& neurobiology 279:103448-103448. 10.1016/j.resp.2020.103448

Instituto Nacional de Estadistica e Informática - Peru. 2020. Estado de la población peruana 2020. Available at https://www.inei.gob.pe/media/MenuRecursivo/publicaciones digitales/Est/Lib1743/Libro .$p d f$.

PeerJ reviewing PDF | (2021:03:58709:2:0:NEW 9 Aug 2021) 
425

426

427

428

429

430

431

432

433

434

435

436

437

438

439

440

441

442

443

444

445

446

447

448

449

450

451

452

453

454

455

456

457

458

459

460

461

462

463

464

465

466

467

468

469

470

471

472

473

474

Instituto Nacional de Salud-Peru. Reporte de evaluación de las pruebas serológicas para SARS-Cov-2 (COVID-19) -Kit de prueba Elecsys Anti SARS-CoV-2 en calidad de demostración (DEMO)-ROCHE. OFICIO N 1836-2020-JEF-OPE-INS. Lima, 2020.

Instituto Nacional de Salud of Peru. Lima, 2020. Reporte de evaluación de las pruebas serológicas para SARS-Cov-2 (COVID-19) -Kit de prueba Elecsys Anti SARS-CoV-2 en calidad de demostración (DEMO)-ROCHE. OFICIO N 1836-2020-JEF-OPE-INS.

Kontou PI, Braliou GG, Dimou NL, Nikolopoulos G, and Bagos PG. 2020. Antibody Tests in Detecting SARS-CoV-2 Infection: A Meta-Analysis. Diagnostics (Basel, Switzerland) 10:319. 10.3390/diagnostics10050319

Kucharski AJ, Russell TW, Diamond C, Liu Y, Edmunds J, Funk S, Eggo RM, Sun F, Jit M, Munday JD, Davies N, Gimma A, van Zandvoort K, Gibbs H, Hellewell J, Jarvis Cl, Clifford S, Quilty BJ, Bosse NI, Abbott S, Klepac P, and Flasche S. 2020. Early dynamics of transmission and control of COVID-19: a mathematical modelling study. The Lancet Infectious Diseases 20:553-558. https://doi.org/10.1016/S14733099(20)30144-4

Lai CC, Wang JH, and Hsueh PR. 2020. Population-based seroprevalence surveys of antiSARS-CoV-2 antibody: An up-to-date review. Int J Infect Dis 101:314-322. 10.1016/j.ijid.2020.10.011

Lancaster GA, Green M, and Lane S. 2006. Reducing bias in ecological studies: an evaluation of different methodologies. Journal of the Royal Statistical Society: Series A (Statistics in Society) 169:681-700. https://doi.org/10.1111/j.1467-985X.2006.00418.x

Martin-Sanz E, Riestra J, Yebra L, Larran A, Mancino F, Yanes-Diaz J, Garrote M, Colmenero M, Montiel E, Molina C, Moreno D, Rodriguez A, Monedero G, Sanz-Fernández R, Gonzalez R, and Esteban-Sanchez J. 2020. Prospective Study in 355 Patients With Suspected COVID-19 Infection: Value of Cough, Subjective Hyposmia, and Hypogeusia. The Laryngoscope 130:2674-2679. https://doi.org/10.1002/lary.28999

Ministerio de salud. 2020. Estudio de seroprevalencia permitirá conocer la magnitud y comportamiento de la pandemia en las regiones. Available at https://www.minsa.gob.pe/newsletter/2020/edicion-36/nota2/index.html (accessed 10/12/2020.

Ministerio de Salud. 2021. Situación Actual COVID-19 Perú 2020-2021. Available at https://www.dge.gob.pe/portal/docs/tools/coronavirus/coronavirus170521.pdf (accessed 30/4/2021.

Muench P, Jochum S, Wenderoth V, Ofenloch-Haehnle B, Hombach M, Strobl M, Sadlowski H, Sachse C, Torriani G, Eckerle I, and Riedel A. 2020. Development and Validation of the Elecsys Anti-SARS-CoV-2 Immunoassay as a Highly Specific Tool for Determining Past Exposure to SARS-CoV-2. Journal of clinical microbiology 58:e01694-01620. 10.1128/JCM.01694-20

Niu Z, Wang T, Hu P, Mei J, and Tang Z. 2020. Chinese Public's Engagement in Preventive and Intervening Health Behaviors During the Early Breakout of COVID-19: Cross-Sectional Study. Journal of medical Internet research 22:e19995-e19995. 10.2196/19995

Pablos-Méndez A, Vega J, Aranguren FP, Tabish H, and Raviglione MC. 2020. Covid-19 in Latin America. BMJ 370:m2939. 10.1136/bmj.m2939

Pang KW, Chee J, Subramaniam S, and Ng CL. 2020. Frequency and Clinical Utility of Olfactory Dysfunction in COVID-19: a Systematic Review and Meta-analysis. Current Allergy and Asthma Reports 20:76. 10.1007/s11882-020-00972-y

Pollán M, Pérez-Gómez B, Pastor-Barriuso R, Oteo J, Hernán MA, Pérez-Olmeda M, Sanmartín JL, Fernández-García A, Cruz I, Fernández de Larrea N, Molina M, Rodríguez-Cabrera $F$, Martín M, Merino-Amador P, León Paniagua J, Muñoz-Montalvo JF, Blanco F, Yotti R, and Group E-CS. 2020. Prevalence of SARS-CoV-2 in Spain (ENE-COVID): a

Peer] reviewing PDF | (2021:03:58709:2:0:NEW 9 Aug 2021) 
475

476

477

478

479

480

481

482

483

484

485

486

487

488

489

490

491

492

493

494

495

496

497

498

499

500

501

502

503

504

505

506

507

508

509

510

511

512

513

514

515

516

517

518

nationwide, population-based seroepidemiological study. Lancet (London, England):S0140-6736(0120)31483-31485. 10.1016/S0140-6736(20)31483-5

Presidencia del Consejo de Ministros. 2020. Decreto Supremo N 044-2020-PCM. Peru.

Qian G, Yang N, Ma AHY, Wang L, Li G, Chen X, and Chen X. 2020. COVID-19 Transmission Within a Family Cluster by Presymptomatic Carriers in China. Clinical Infectious Diseases 71:861-862. 10.1093/cid/ciaa316

ROCHE S.A.C. 2020. Inmunoanálisis para detectar cualitativamente anticuerpos (incluidos los de tipo $\lg G$ ) contra el coronavirus del síndrome respiratorio agudo grave de tipo 2 (SARS-CoV-2). Available at https://diagnostics.roche.com/es/es/products/params/elecsys-anti-sars-cov-2.html (accessed 10/07/2020.

Rostami A, Sepidarkish M, Leeflang MMG, Riahi SM, Nourollahpour Shiadeh M, Esfandyari S, Mokdad AH, Hotez PJ, and Gasser RB. 2020. SARS-CoV-2 seroprevalence worldwide: a systematic review and meta-analysis. Clinical microbiology and infection : the official publication of the European Society of Clinical Microbiology and Infectious Diseases:S1198-1743X(1120)30651-30650. 10.1016/j.cmi.2020.10.020

Rousson V, Rosselet PC, and Paccaud F. 2017. Selection bias in ecological studies. Public Health 153:103-106. 10.1016/j.puhe.2017.09.001

Segovia-Juarez J, Castagnetto JM, and Gonzales GF. 2020. High altitude reduces infection rate of COVID-19 but not case-fatality rate. Respiratory physiology \& neurobiology 281:103494-103494. 10.1016/j.resp.2020.103494

Silva AAMd, Lima-Neto LG, Azevedo CdMPeSd, Costa LMMd, Bragança MLBM, Barros Filho AKD, Wittlin BB, Souza BFd, Oliveira BLCAd, Carvalho CAd, Thomaz EBAF, SimõesNeto EA, Leite Júnior JF, Cosme LMSS, Campos MAG, Queiroz RCdS, Costa SS, Carvalho VAd, Simões VMF, Alves MTSSdBe, and Santos AMd. 2020. Populationbased seroprevalence of SARS-CoV-2 and the herd immunity threshold in Maranhão. Revista de Saúde Pública 54.

Thomson TM, Casas F, Guerrero HA, Figueroa-Mujíca R, Villafuerte FC, and Machicado C. 2021. Potential Protective Effect from COVID-19 Conferred by Altitude: A Longitudinal Analysis in Peru During Full Lockdown. High Alt Med Biol. 10.1089/ham.2020.0202

Vidal-Anzardo M, Solis G, Solari L, Minaya G, Ayala-Quintanilla B, Astete-Cornejo J, LuqueAguilar A, Jorge A, Rojas N, Cardenas F, and Soto A. 2020. Evaluación en condiciones de campo de una prueba serológica rápida para detección de anticuerpos lgM e lgG contra SARS-CoV-2. Revista Peruana de Medicina Experimental y Salud Publica 37:203-209.

Woolcott OO, and Bergman RN. 2020. Mortality Attributed to COVID-19 in High-Altitude Populations. High Alt Med Biol 21:409-416. 10.1089/ham.2020.0098

World Health Organization. 2020a. Laboratory testing for coronavirus disease (COVID-19) in suspected human cases: interim guidance.

World Health Organization. 2020b. WHO Coronavirus Disease (COVID-19) Dashboard. Available at https://covid19. who.int/ (accessed Dec 20, 2020.

Xu L, Mao Y, and Chen G. 2020. Risk factors for 2019 novel coronavirus disease (COVID-19) patients progressing to critical illness: a systematic review and meta-analysis. Aging 12:12410-12421. 10.18632/aging.103383 


\section{Table $\mathbf{1}$ (on next page)}

Table 1: Population characteristics according to the study settings 
1 Table 1: Population characteristics according to the study settings

\begin{tabular}{|c|c|c|c|c|c|}
\hline & $\begin{array}{l}\text { TOTAL } \\
(\mathrm{n}=1924)\end{array}$ & $\begin{array}{l}\text { Cusco city } \\
(n=640)\end{array}$ & $\begin{array}{l}\text { Periphery of Cusco } \\
(\mathrm{n}=876)\end{array}$ & $\begin{array}{l}\text { Quillabamba } \\
(n=408)\end{array}$ & p-value \\
\hline Gender & $1096(57.1 \%)$ & $359(56.3 \%)$ & $500(57.1 \%)$ & $237(58.2 \%)$ & 0.822 \\
\hline \multicolumn{6}{|l|}{ Female } \\
\hline Age: Mean (S.D.) & $42.47(16.5)$ & $42.8(16.2)$ & $42.5(16.8)$ & $42.81(16.5)$ & 0.884 \\
\hline \multicolumn{6}{|l|}{ Age group (years) } \\
\hline$>=18,<40$ & $876(46.5 \%)$ & $298(47.3 \%)$ & $403(46.8 \%)$ & $175(44.4 \%)$ & 0.843 \\
\hline $40-59$ & $702(37.2 \%)$ & $235(37.3 \%)$ & $313(36.3 \%)$ & $154(39.1 \%)$ & \\
\hline$>60$ & $308(16.3 \%)$ & $97(15.4 \%)$ & $146(16.9 \%)$ & $65(16.5 \%)$ & \\
\hline $\begin{array}{l}\text { People living in the } \\
\text { same house: Mean } \\
\text { (SD) }\end{array}$ & $5.98(3.43)$ & $6.24(3.40)$ & $6.16(3.58)$ & $5.04(2.92)$ & $<0.001$ \\
\hline $\begin{array}{l}\text { Previous SARS- } \\
\text { COV-2 test (rapid test } \\
\text { or molecular) }\end{array}$ & $758(39.7 \%)$ & $242(38.1 \%)$ & $328(37.7 \%)$ & $188(46.7 \%)$ & 0.006 \\
\hline Obesity & $332(18.4 \%)$ & $86(13.2 \%)$ & $152(18.3 \%)$ & $94(26.5 \%)$ & $<0.001$ \\
\hline $\begin{array}{l}\text { No symptoms in the } \\
\text { last } 3 \text { months }\end{array}$ & $772(40.2 \%)$ & $236(36.9 \%)$ & $300(34.4 \%)$ & $236(57.9 \%)$ & $<0.001$ \\
\hline \multicolumn{6}{|l|}{$\begin{array}{l}\text { Self-reported } \\
\text { comorbidities }\end{array}$} \\
\hline & . & . & . & . & . \\
\hline Hypertension & $128(6.7 \%)$ & $43(6.7 \%)$ & $55(6.3 \%)$ & $30(7.4 \%)$ & 0.763 \\
\hline Diabetes & $85(4.4 \%)$ & $19(3.0 \%)$ & $37(4.2 \%)$ & $29(7.1 \%)$ & 0.006 \\
\hline Asthma & $29(1.5 \%)$ & $10(1.6 \%)$ & $13(1.5 \%)$ & $6(1.5 \%)$ & 0.990 \\
\hline Cardiac disease & $12(0.6 \%)$ & $5(0.8 \%)$ & $6(0.7 \%)$ & $1(0.3 \%)$ & 0.543 \\
\hline Renal disease & $19(1.0 \%)$ & $5(0.8 \%)$ & $12(1.4 \%)$ & $2(0.5 \%)$ & 0.271 \\
\hline Cancer & $10(0.5 \%)$ & $4(0.6 \%)$ & $4(0.5 \%)$ & $2(0.5 \%)$ & 0.900 \\
\hline
\end{tabular}




\section{Table 2 (on next page)}

Table 2: Prevalence of serum antibodies to SARS-CoV-2 in the general population at different altitudes in Cusco, Peru, according to individual/family characteristics

Models adjusted for age, gender, and study setting. 
1 Table 2: Prevalence of serum antibodies to SARS-CoV-2 in the general population at different altitudes in

2 Cusco, Peru, according to individual/family characteristics

3

\begin{tabular}{|c|c|c|}
\hline & $\begin{array}{l}\% \text { seropositive to SARS- } \\
\text { CoV-2 antibodies }\end{array}$ & Adjusted PR \\
\hline Global prevalence & $33.1 \%(30.1-36.4 \%)$ & \\
\hline \multicolumn{3}{|l|}{ Gender } \\
\hline Male & $31.1 \%(27.3-35.2 \%)$ & 1 \\
\hline Female & $34.6 \%(31.2-38.3 \%)$ & $1.09(0.97-1.24) \ldots$ \\
\hline \multicolumn{3}{|l|}{ Study setting } \\
\hline Cusco city & $38.8 \%(33.4-44.9 \%)$ & $1.85(1.41-2.43)$ \\
\hline Periphery of Cusco & $34.9 \%(30.4-40.1 \%)$ & $1.71(1.31-2.22)$ \\
\hline Quillabamba & $20.3 \%(16.2-25.6 \%)$ & $\ldots \ldots .1$ \\
\hline \multicolumn{3}{|l|}{ Age group (years) } \\
\hline$>=18,<40$ & $34.8 \%(31.0-39.1 \%)$ & 1 \\
\hline $40-59$ & $35.8 \%(31.8-40.2 \%)$ & $0.99(0.86-1.14)$ \\
\hline$>60$ & $24.7 \%(19.7-30.9 \%)$ & $0.65(0.51-0.83) \ldots \ldots$ \\
\hline \multicolumn{3}{|l|}{ Education level (years) } \\
\hline$<7$ & $34.2 \%(26.9-43.3 \%)$ & 1 \\
\hline $7-11$ & $39.2 \%(34.4-44.7 \%)$ & $1.09(0.86-1.40)$ \\
\hline$>12$ & $30.3 \%(26.9-34.0 \%)$ & $0.79(0.61-1.03) \ldots \ldots$ \\
\hline \multicolumn{3}{|l|}{$B M I$} \\
\hline Normal & $34.1 \%(30.0-38.6 \%)$ & 1 \\
\hline Overweight & $31.1 \%(27.1-35.7 \%)$ & $0.95(0.81-1.13)$ \\
\hline Obese & $35.5 \%(30.2-41.8 \%)$ & $1.17(0.95-1.44) \ldots$ \\
\hline \multicolumn{3}{|c|}{ Number of people living together } \\
\hline $1-2$ & $20.5 \%(14.4-29.1 \%)$ & 1 \\
\hline $3-5$ & $31.8 \%(27.6-36.7 \%)$ & $1.47(1.01-2.15)$ \\
\hline $6-10$ & $37.5 \%(31.9-44.0 \%)$ & $1.68(1.14-2.46)$ \\
\hline$>11$ & $38.7 \%(28.1-53.2 \%)$ & $1.71(1.07-2.73) \ldots$ \\
\hline \multicolumn{3}{|c|}{ Self-report of COVID-19 case at home } \\
\hline No & $26.2 \%(22.9-29.9 \%)$ & 1 \\
\hline Yes & $50.2 \%(44.4-56.7 \%)$ & $1.90(1.60-2.27) \ldots$ \\
\hline \multicolumn{3}{|l|}{ Death at home (any cause) } \\
\hline No & $31.9 \%(28.7-35.3 \%)$ & 1 \\
\hline Yes & $50.8 \%(38.4-67.2 \%)$ & $1.50(1.11-2.04) \ldots$ \\
\hline \multicolumn{3}{|c|}{$\begin{array}{l}\text { Previous SARS-COV-2 test (rapid test } \\
\text { or molecular) }\end{array}$} \\
\hline No & $28.7 \%(25.3-32.6 \%)$ & 1 \\
\hline Yes & $39.9 \%(35.7-44.7 \%)$ & $1.46(1.26-.1 .69)$ \\
\hline
\end{tabular}

5 Models adjusted for age, gender, and study setting. 


\section{Table 3 (on next page)}

Table 3: Factors associated with positivity to SARS-CoV-2 in the general population in a high-altitude setting in Peru.

Models adjusted for age, gender, and study setting. 
1 Table 3: Factors associated with positivity to SARS-CoV-2 in the general population in a high-altitude 2 setting in Peru

$\begin{array}{lll}\text { Negatives } & \text { Positives } & \text { Adjusted PR } \\ 1284(100 \%) & 636(100 \%) & \end{array}$

SELF-REPORTED

COMORBIDITIES

Hypertension

Diabetes

Asthma

Cardiac disease

Renal disease

Cancer

DEVELOPED SOME OF THESE SYMPTOMS IN THE LAST 3 MONTHS BEFORE THE SURVEY

\begin{tabular}{|c|c|c|c|}
\hline No symptoms & $584(45.5 \%)$ & $188(29.6 \%)$ & $0.68(0.58-0.81)$ \\
\hline Dysgeusia/Dysosmia & $18(1.4 \%)$ & $118(18.6 \%)$ & $2.74(2.41-3.12) .$. \\
\hline Respiratory distress & $23(1.8 \%)$ & $65(10.2 \%)$ & $2.18(1.84-2.62) \ldots$ \\
\hline Fever & $108(8.4 \%)$ & $138(21.7 \%)$ & $1.76(1.52-2.05) .$. \\
\hline General discomfort & $136(10.6 \%)$ & $163(25.6 \%)$ & $1.75(1.51-2.03) .$. \\
\hline Cough & $174(13.5 \%)$ & $178(27.9 \%)$ & $1.68(1.48-1.92) .$. \\
\hline Muscle pain & $146(11.4 \%)$ & $149(23.4 \%)$ & $1.57(1.35-1.82) \ldots$ \\
\hline Nasal congestion & $105(8.2 \%)$ & $102(16.0 \%)$ & $1.47(1.23-1.75) .$. \\
\hline Back pain & $216(16.8 \%)$ & $182(28.6 \%)$ & $1.46(1.26-1.71) .$. \\
\hline Diarrhea & $96(7.5 \%)$ & $82(12.9 \%)$ & $1.40(1.16-1.70) .$. \\
\hline Headache & $412(32.0 \%)$ & $275(43.2 \%)$ & $1.24(1.08-1.44) .$. \\
\hline Sore throat & $272(21.2 \%)$ & $167(26.2 \%)$ & $1.11(0.94-1.30) .$. \\
\hline \multicolumn{4}{|l|}{ BEHAVIORS } \\
\hline Always wear a face shield & $338(27.6 \%)$ & $139(23.0 \%)$ & $0.73(0.60-0.89) \ldots$ \\
\hline Always wear a face mask & $1085(85.8 \%)$ & $511(81.5 \%)$ & $0.76(0.63-0.92) \ldots$ \\
\hline $\begin{array}{l}\text { Always use alcohol to hand } \\
\text { disinfection }\end{array}$ & $1039(82.7 \%)$ & $486(77.5 \%)$ & $0.78(0.65-0.92) \ldots$ \\
\hline Always wash hands & $1036(83.7 \%)$ & $484(78.3 \%)$ & $0.83(0.69-0.99) \ldots$ \\
\hline $\begin{array}{l}\text { Always stay more than } 1 \text { meter away } \\
\text { from other people }\end{array}$ & $945(75.3 \%)$ & $443(70.8 \%)$ & $0.85(0.73-0.99) \ldots$ \\
\hline
\end{tabular}



Always wear gloves
$69(5.9 \%)$
$31(5.2 \%)$
$0.82(0.59-1.12)$

3 Models adjusted for age, gender, and study setting.

4 


\section{Table 4 (on next page)}

Table 4: Differences between cities and seropositivity to SARS-COV-2 antibodies in settings of Cusco

M.a.s.l.: meters above the sea level 
1 Table 4: Differences between cities and seropositivity to SARS-COV-2 antibodies in settings of Cusco

\begin{tabular}{|c|c|c|c|}
\hline & Cusco city & $\begin{array}{l}\text { Periphery of } \\
\text { Cusco }\end{array}$ & Quillabamba \\
\hline & $(\mathrm{n}=640)$ & $(\mathrm{n}=876)$ & $(\mathrm{n}=408)$ \\
\hline $\begin{array}{l}\% \text { seropositive to } \\
\text { SARS-CoV-2 } \\
\text { antibodies }\end{array}$ & $\begin{array}{c}38 \cdot 8 \% \\
(33 \cdot 4-44 \cdot 9 \%)\end{array}$ & $\begin{array}{c}34 \cdot 9 \% \\
(30 \cdot 4-40 \cdot 1 \%)\end{array}$ & $\begin{array}{c}20 \cdot 3 \% \\
(16 \cdot 2-25 \cdot 6 \%)\end{array}$ \\
\hline Altitude (m.a.s.l.) & 3330 & 3330 & 1050 \\
\hline $\begin{array}{l}\text { Demographic } \\
\text { density (aprox. } \\
\text { inhabitants } / \mathrm{km}^{2} \text { ) }\end{array}$ & 1000 & 1100 & 10 \\
\hline Access roads & \multicolumn{2}{|c|}{$\begin{array}{l}\text { Multiple land access routes, from } \\
\text { within and outside the region. } \\
\text { Air access from Lima (capital of } \\
\text { Peru) }\end{array}$} & $\begin{array}{l}\text { Only two land access } \\
\text { routes, from the city } \\
\text { of Cusco and nearby } \\
\text { cities }\end{array}$ \\
\hline $\begin{array}{l}\text { Temperature }\left({ }^{\circ} \mathrm{C}\right) \\
\text { in September }\end{array}$ & \multicolumn{2}{|c|}{$7.9[3.6-13.5]$} & $14.6[10.2-19.2]$ \\
\hline
\end{tabular}

2 M.a.s.l.: meters above the sea level 


\section{Figure 1}

Figure 1. Map of Cusco, provinces, and cities.

Cusco has thirteen provinces (middle image). The capital of La Convención Province is

Quillabamba (yellow dot), located at 1050 m.a.s.I. The Cusco Province (blue arrow), at 3300 m.a.s.I., is inhabited in only one sector located in the valleys (blue mark in A), which include the five cities where the research was carried out (B).
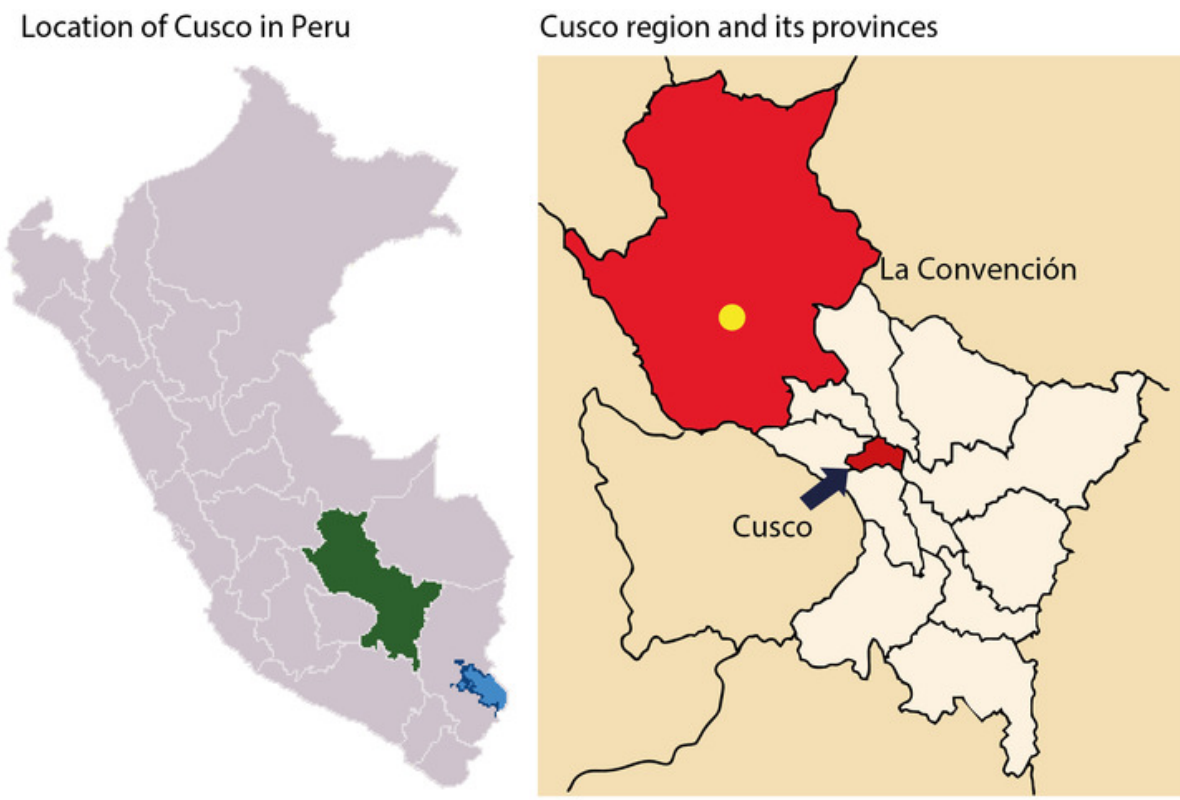

Cusco's cities

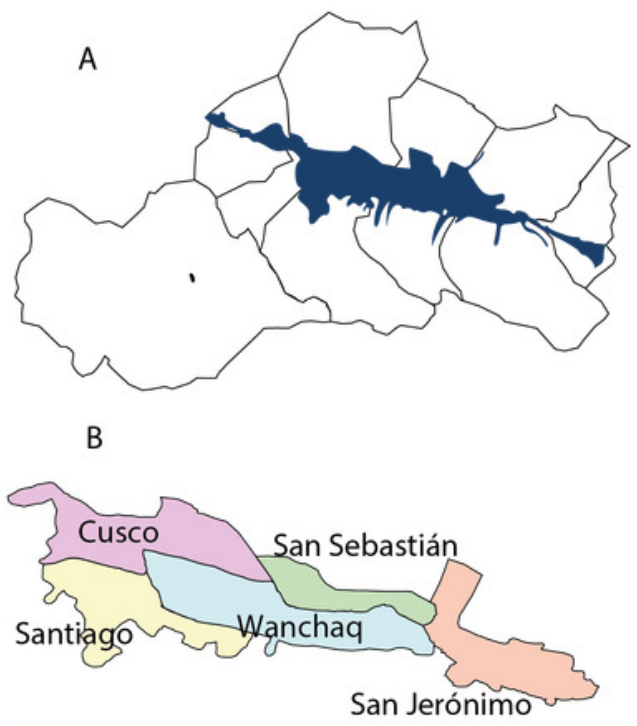

